\title{
Circular Economy in EAF Process: How to Make It Sustainable with Zero Waste Project in Ferriere Nord
}

\author{
Loris Bianco", Sergio Porisiensi, Giulia Baracchini, Laura Battigelli, Carlo Ceschia \\ Ferriere Nord S.p.A., Environmental Department, 33010 Osoppo, Italy
}

Copyright $\odot 2018$ by authors, all rights reserved. Authors agree that this article remains permanently open access under the terms of the Creative Commons Attribution License 4.0 International License

\begin{abstract}
Ferriere Nord S.p.A., a steel producer from ferrous scrap, in 1998 decided to start the "Zero Waste" project to transform the main process wastes into products to be re-used in a logic of circular economy. 20 years later, since "Zero Waste" project started, the main secondary materials of the EAF (Electric Arc Furnace) process have been reviewed and re-evaluated: the slag from EAF, the slag from ladle furnace, the EAF dust, the iron scale and the refractories. Many companies are now involved in dealing with these materials and established important and stable relations of symbiosis to prepare, transform and finally use them. A company network trusts on regular availability and quality of the new products: scrap dealers, lime producers, zinc producers, aggregates and asphalt producers, highway companies... Finally, reuse of these materials allows saving equivalent quantities of natural resources: iron ore, basalt, porphyry, limestone, zinc and lead minerals.
\end{abstract}

Keywords EAF, Scrap, Slag, Dust, Granella ${ }^{\circledR}$

\section{Introduction}

Ferriere Nord S.p.A. is a company based in Osoppo that produces steel bars and wire rod with a process route with Electric Arc Furnace (EAF) for ferrous scrap melting, ladle furnace (LF) for chemical refinement, continuous casting for solidification and hot rolling mill for getting final shape and properties of steel products. In 1998 the company decided to implement the "Zero Waste" project [1], [2]. The underlying idea was to study and transform the main wastes into products to be re-used in the same or in other industrial processes. The driving forces of this decision were the growing difficulty to find economic ways to dispose wastes, the growing tightness of environmental rules and finally the growing awareness in all stakeholders of our activity about environmental issues. In other words we were forced to find a sustainable way to our business.

The project lasted for many years and today is still going on: now it focuses on increasing quality of new products and optimizing transformation processes taking in consideration updated economic and environmental aspects.

At a distance of 20 years since "Zero Waste" project started, we can state that all secondary materials have been reviewed and re-evaluated in a circular economy perspective. The new developed materials replace natural ones that otherwise should be extracted from mines or quarries: basalt, porphyry, limestone, iron ore, zinc and lead minerals are replaced with products obtained from slags of EAF and LF, from EAF dust, from iron scale and refractories. We established an important and stable relation with many users of these new products, creating a network that now trusts on regular availability and quality of them.

In this paper we describe our experience in the transformation of our business from a linear economy to a circular one related to slags, dusts, iron scale and spent refractories.

\section{Methods}

The transformation from a linear economy to a circular one of the main wastes of a steel plant starts in laboratory looking at analysis and properties of the material. Another important information to start the process is also the possible destination process, i.e. the final client of the material. In Figure 1 we show the process adopted to transform a waste in a product. The second step is to evaluate at laboratory scale the compatibility of the chosen solution. Than as in all new processes it is necessary to grow through laboratory tests, pilot plant and at the end industrial one. All this activity must be performed with the involvement of the final client to assure that new products are in accordance with its needs. When new products are available, tested and accepted, considering not only chemical, environmental, or performance properties, but also economical ones, it is necessary to implement a factory production control (fpc) to assure quality during time. This process, apparently obvious, is a must if we want to transform a waste in a product, and it is valid also in the special case where the final client is inside the company. 


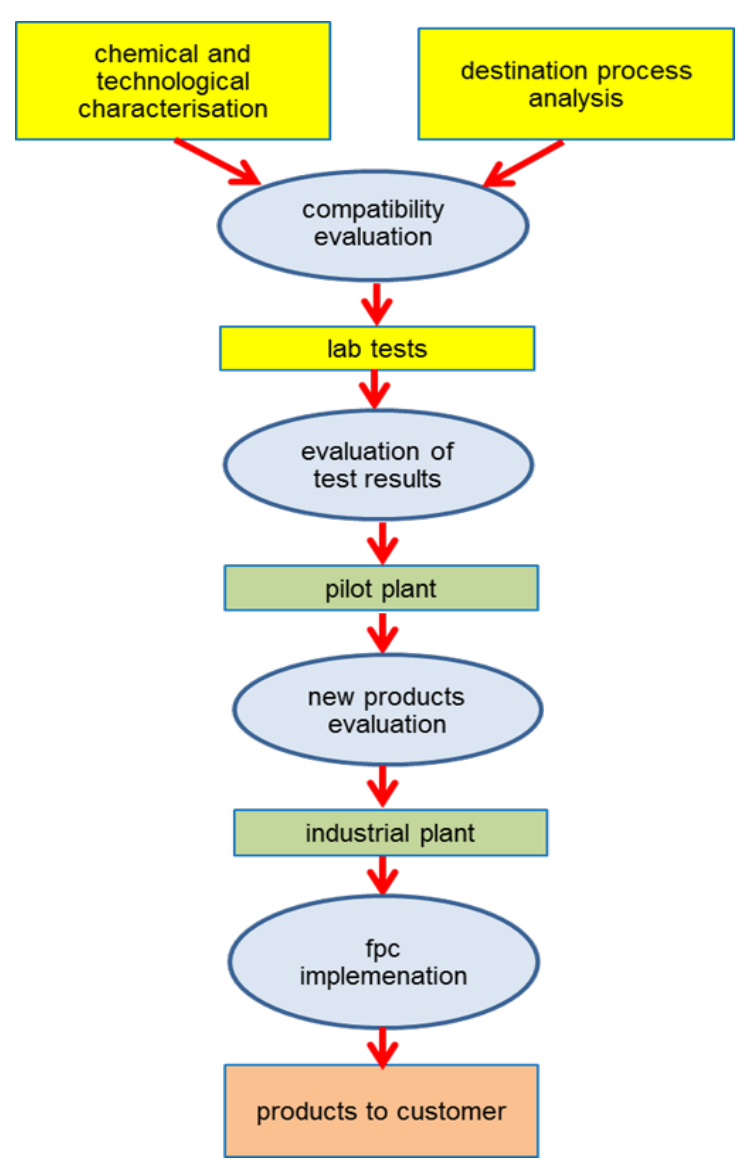

Figure 1. Process adopted in Zero waste project

The following materials were tackled in Zero Waste Project: EAF slag, EAF dust, LF slag and refractories, iron scale. This paper describes their origin, characteristics and the transformation process to the final use for this material. We consider also the case of the steel scrap, the main input material in our process which is part of an already existing and consolidated circular economy loop.

\subsection{EAF Slag}

In EAF process, the addition of lime and the flotation of oxides from scrap create a second liquid phase above liquid steel: the slag mainly consists of oxides of iron, calcium, silicon. The quantity is remarkable: $15 \%$ by weight of the steel product and a comparable quantity in volume (in Ferriere Nord plant about 200.000 tpy). A typical analysis of EAF slag is reported in table 1, an average of more than 500 recent samples determined by XRF and expressed as oxides.

Table 1. 2017 average analysis of EAF slag, weight $\%$

\begin{tabular}{|c|c|c|c|c|c|c|}
\hline $\mathrm{FeO}$ & $\mathrm{CaO}$ & $\mathrm{SiO}_{2}$ & $\mathrm{Al}_{2} \mathrm{O}_{3}$ & $\mathrm{MgO}$ & $\mathrm{MnO}$ & $\mathrm{Cr}_{2} \mathrm{O}_{3}$ \\
\hline 37,0 & 24,8 & 14,9 & 7,5 & 6,3 & 4,8 & 3,4 \\
\hline
\end{tabular}

EAF slag is extracted from EAF at a temperature of $1600^{\circ} \mathrm{C}$ and is solidified on a bed of previous extracted slag. Cooling to room temperature initially is done by air than with water sprays.

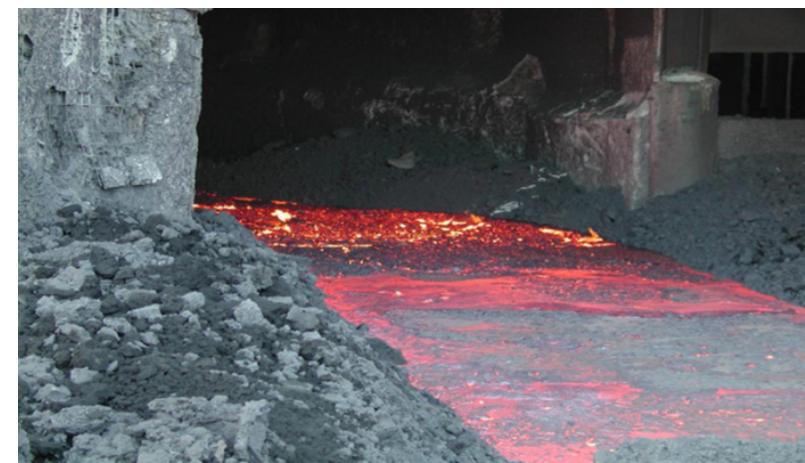

Figure 2. EAF slag is extracted from furnace liquid at $1600^{\circ} \mathrm{C}$

The analysis and the technological tests on the EAF slag showed that we were facing a very "hard" material that could be interesting for road pavements because of a potential prolongation of service life of the asphalt layer attainable with it. Together with the regional highway network operator (Autovie Venete) we started a research and testing program (laboratory 1995, pilot scale 1998) that led to the development of a pilot plant for the production of asphalt aggregates [3] [4]. We named it Granella ${ }^{\circledR}$. This is the trade mark that Ferriere Nord registered for the new product. The pilot plant (1998) allowed consolidation of the use on the market: since that date, most of the motorway draining asphalt pavements of the regional network is made with this material, replacing basalt or porphyry of natural origin.

In table 2 we report the results of two parameters, Polished Stone Value (PSV) and Los Angeles Test (LA) typical of Granella ${ }^{\circledR}$ and the comparison with values of natural hard rocks. Values obtained confirm a very hard material with interesting properties particularly in use in upper road surfaces where safety is related to high grip between road and wheels.

Table 2. Comparison of PSV and LA tests in natural hard rocks and Granella

\begin{tabular}{|c|c|c|}
\hline material & PSV test & LA test \\
\hline basalt & $0,42-0,45$ & $14-17$ \\
\hline andesite & $0,46-0,50$ & $18-20$ \\
\hline diabase & $0,45-0,49$ & $15-18$ \\
\hline porfiry $\left.^{(}\right)$ & $0,45-0,48$ & $16-20$ \\
\hline Granella $^{\circledR}$ & $>0,55$ & $13-18$ \\
\hline
\end{tabular}

Figure 3 shows a typical use of Granella ${ }^{\circledR}$ in highway in the upper part where a draining asphalt course is laid.

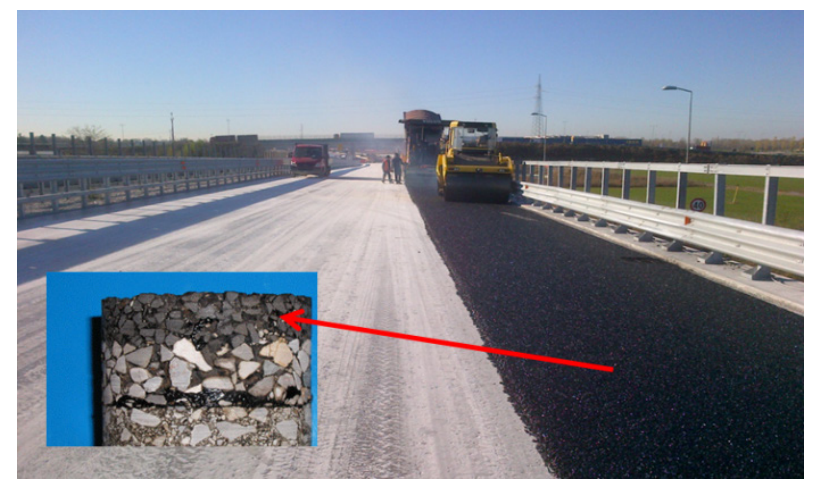

Figure 3. Granella ${ }^{\circledR}$ used as draining asphalt paving 
In 2004, we built the final plant (figure 4) to handle the whole EAF slag produced by Ferriere Nord.

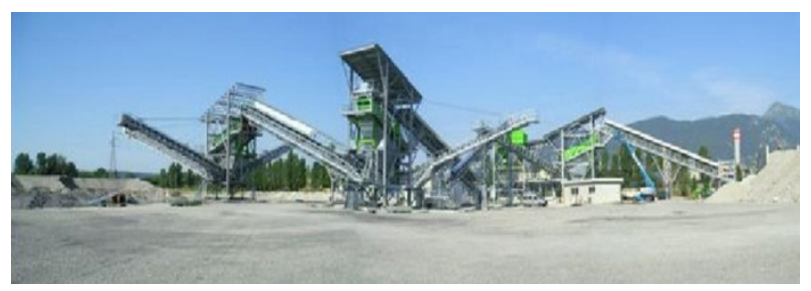

Figure 4. Granella ${ }^{\circledR}$ plant in Ferriere Nord

Since then all EAF slag production is devoted to the new product instead of wasting and landfilling it. In this new activity we are the producers of the new synthetic aggregate, Autovie Venete is the end user, but many other companies are involved in preparation of asphalts, testing, certifying, and using the new products.

A Factory Production Control (fpc) of this new product is implemented and certified according to European
Regulation (CPR 305/2011). The new product is registered according to the rules of REACH-ECHA the European register for chemical substances. In the Figure 5 it is shown an evaluation of the analysis of Ferriere Nord's Granella ${ }^{\circledR}$ and its compatibility with limits for steel slag "EAF-C" which is one of the criteria to allow use of deposited technical data and safety technical sheets.

In 2005, the material was certified and sine than sold under CE marking according to the CPR (European Construction Products Regulation).

The experience gained with Granella ${ }^{\circledR}$ was "exported" in Basilicata Region in the south of Italy where, in the town of Potenza, Ferriere Nord S.p.A. owns another steel plant. With this new product, also in that area, we established an industrial symbiosis experience based on circular economy concept. Also in Potenza plant all EAF slag is transformed in product Granella ${ }^{\circledR}$ which is used mainly to highway asphalt paving.

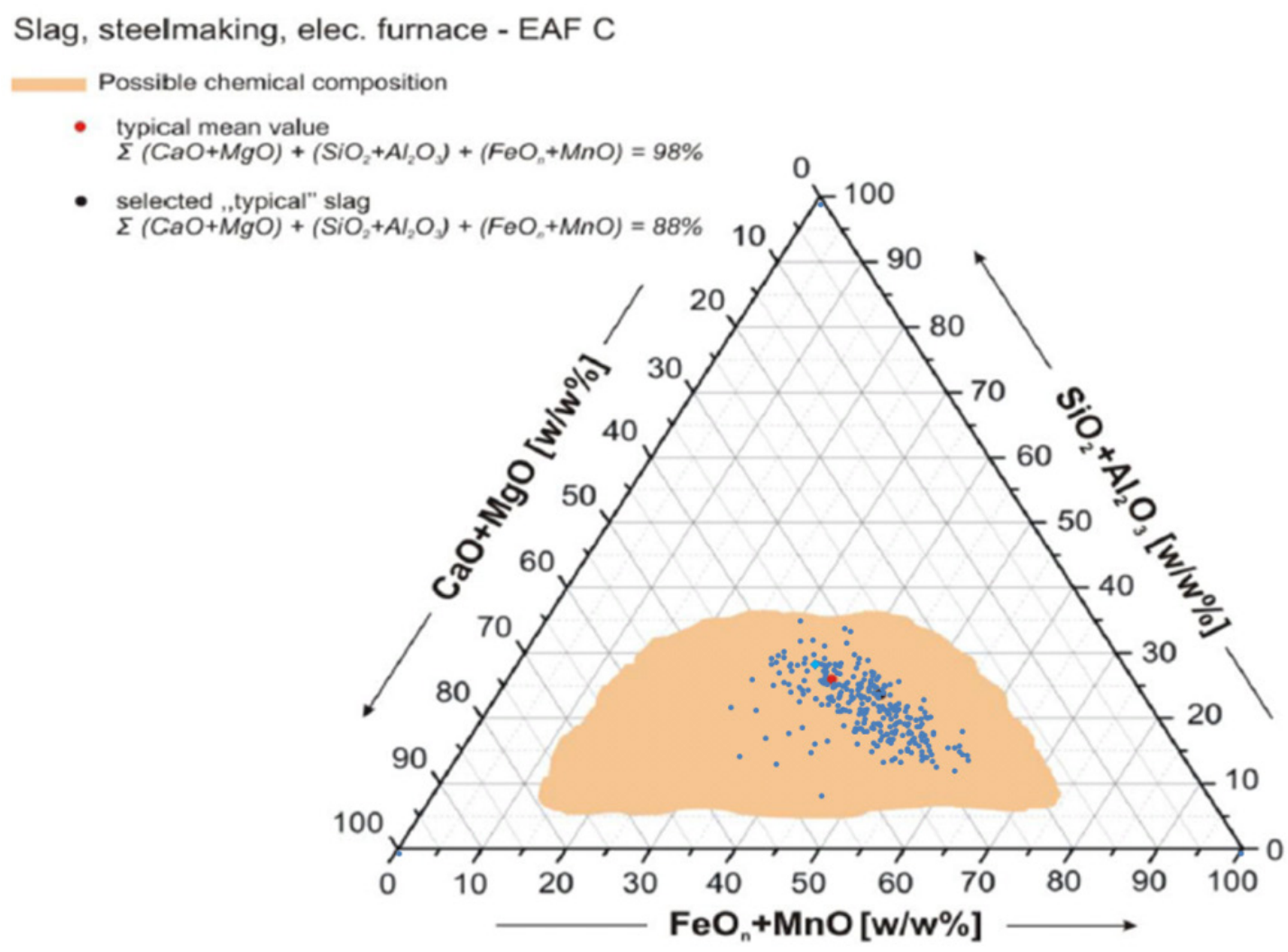

Figure 5. Granella ${ }^{\circledR}$ analysis and comparison with possible chemical composition for EAF-C slag (brown color) 


\subsection{EAF Dust}

Analysis of dust collected by dedusting system in EAF process showed that dust is a zinc and lead rich mineral ( $\mathrm{Zn}$ $20-30 \%, \mathrm{~Pb} 5 \%$ ); richer than natural ores. A collaboration with an engineering company gave us the opportunity for laboratory testing, pilot plant and in 1998 the first industrial plant was settled for the production of zinc cathodes from steel powders with an original electrowinning process.

The process is described in figure 6 . Leaching in an ammonium chloride neutral solution was the original idea, compatible with EAF dust that usually contains chlorides. Leaching affects mainly zinc, lead and all heavy metals, which leaves insoluble iron oxide to be separated for recycling. The solution is than treated with zinc to separate all heavy metals present as $\mathrm{Pb}$ cements which are delivered to secondary lead industry. The solution obtained is fed to electrowinning process to produce zinc cathodes. After addition of reactants (NH3), $\mathrm{pH}$ and build up control, the depleted solution is recirculated to leaching phase. Excess of $\mathrm{NaCl}$ and $\mathrm{KCl}$ is extracted as salts to be sold.

We designed the process with the "Zero Waste" philosophy: all the materials must be tackled without leaving parts to landfill.
The Ezinex ${ }^{\circledR}$ process [5] was active at Ferriere Nord for two years, and was able to handle the complete production of EAF powders at that time, with a final zinc production of about 2000 tpy.

Ezinex ${ }^{\circledR}$ alone was not the definitive solution because the installed plant was too small for the whole EAF dust production of Ferriere Nord, in the meanwhile increased, and it was small if compared to standard zinc production facilities. With the installed capacity some auxiliary parts were not economically justified, automatic extraction and smelting of cathodes for example. This absence was cause of production costs and economical downgrading of final product so affecting competitiveness of new product on the market. Ferrous residue was recycled in EAF and this was not the appropriate way to handle it. A pyrometallurgical processes as Indutec ${ }^{\circledR}$ would have been necessary to complete the treatment line: we installed a prototype of it in the frame of a research activity financed by European ECSC [6]. In the meantime, zinc producers become more competitive in the production of zinc from EAF dusts; therefore Ferriere Nord decided to deliver EAF dust to that chain. In this way we closed a circular economy loop saving zinc and lead minerals: since than roughly 25.000 tpy of zinc with $25 \% \mathrm{Zn}$ content are saved instead of wasting and landfilling it.

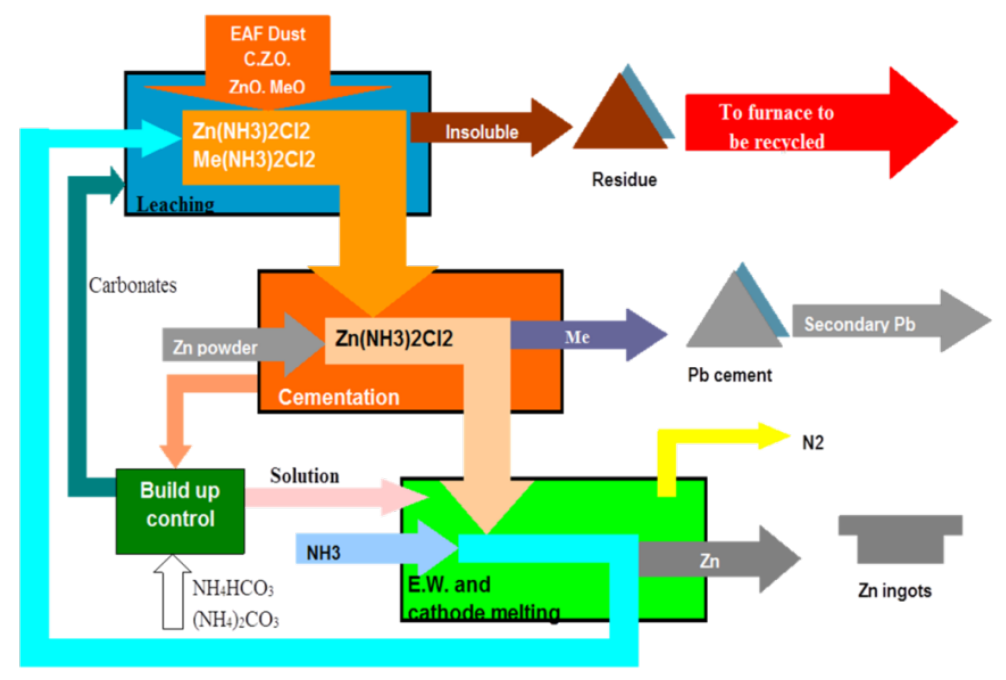

Figure 6. Ezinex ${ }^{\circledR}$ process

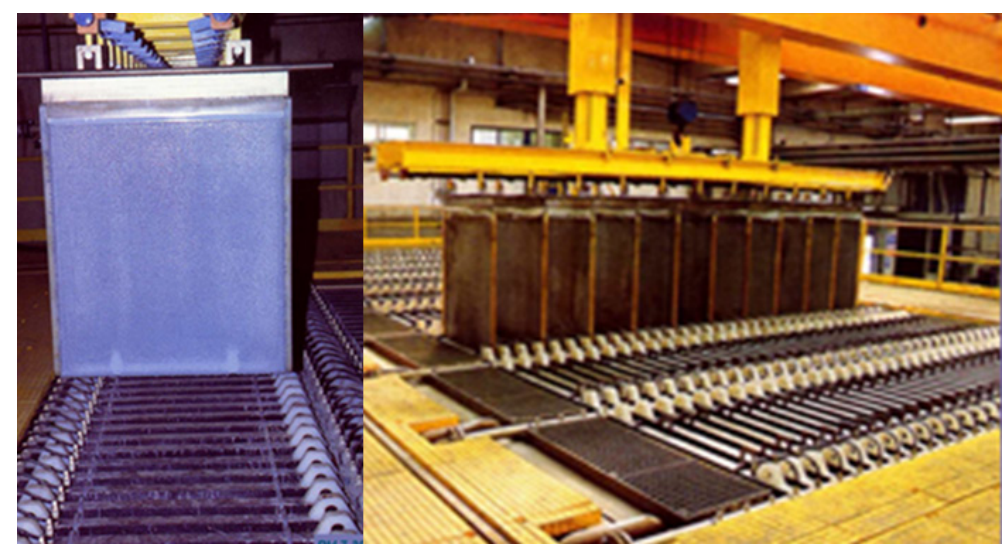

Figure 7. Ezinex $^{\circledR}$ process: extraction of zinc cathodes. 


\subsection{LF Slag and Refractories}

LF slag and refractories are often heterogeneous materials, they are difficult to handle, especially because they quickly transform into a very fine powder with a high content of $\mathrm{CaO}$ and $\mathrm{MgO}$.

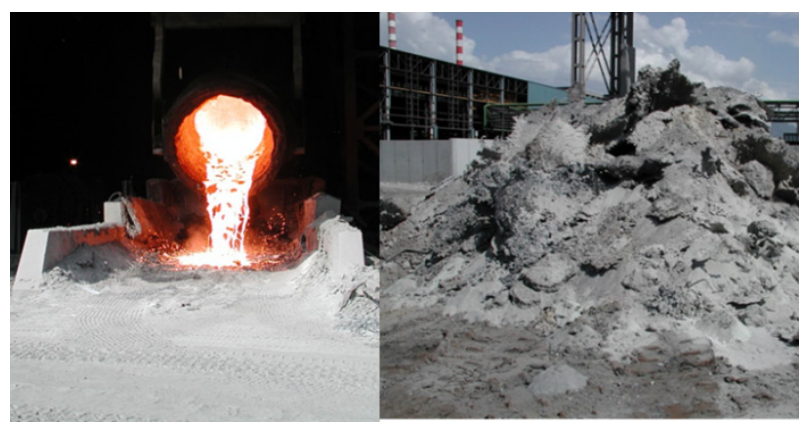

Figure 8. LF slag poured at $1600^{\circ} \mathrm{C}$ and powder after cooling.

We started with a study of a possible re-use in EAF in partial substitution of lime. Some pilot tests demonstrated the feasibility of the hypothesis. A typical analysis of LF slag is reported in table 3, an average of more than 500 recent samples determined by XRF and expressed as oxides.
Table 3. 2017 average analysis of LF slag, weight \%

\begin{tabular}{|c|c|c|c|c|c|c|}
\hline $\mathrm{CaO}$ & $\mathrm{SiO}_{2}$ & $\mathrm{MgO}$ & $\mathrm{Al}_{2} \mathrm{O}_{3}$ & $\mathrm{~S}$ & $\mathrm{FeO}$ & $\mathrm{MnO}$ \\
\hline 54,8 & 22,8 & 11,3 & 7,9 & 1,4 & 0,8 & 0,5 \\
\hline
\end{tabular}

In the melting shop also other materials are available, in table 4 their composition is reported, compared with LF slag and also it is indicated an average expected after mixing.

Table 4. Average analysis of other materials, weight $\%$

\begin{tabular}{|c|c|c|c|c|c|}
\hline Materials & $\mathrm{CaO}$ & $\mathrm{MgO}$ & $\mathrm{SiO}_{2}$ & $\mathrm{Al}_{2} \mathrm{O}_{3}$ & $\mathrm{C}$ \\
\hline LF slag & $50-60$ & $10-15$ & $15-25$ & $5-10$ & \\
\hline LF refractories & $50-60$ & $30-40$ & & & $2-3$ \\
\hline Tundish refractories & $10-15$ & 50 & $15-20$ & $5-8$ & \\
\hline EAF refractories & $10-15$ & $50-60$ & & & $5-8$ \\
\hline Average for injection & 55 & 15 & 15 & 5 & \\
\hline
\end{tabular}

The process [7] was developed and installed: material solidification, cooling and following transformation in powder, magnetic separation of metal parts, refractory grinding, storage and pneumatic transport to EAF and subsequent re-injection. Figure 9, 10, 11.

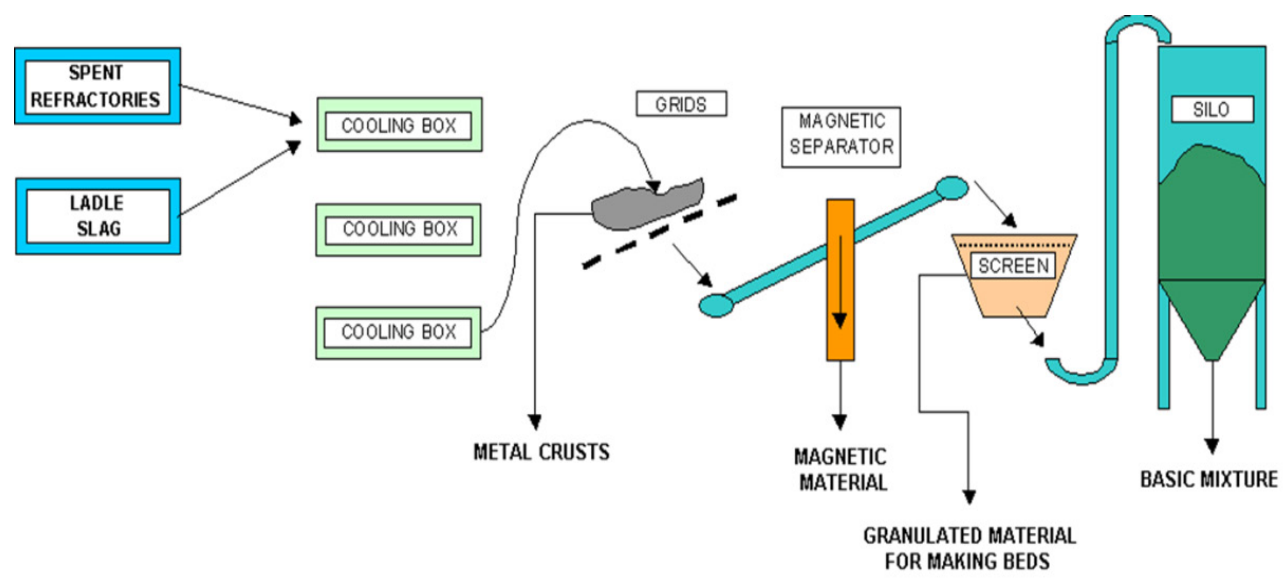

Figure 9. LF slag preparation plant

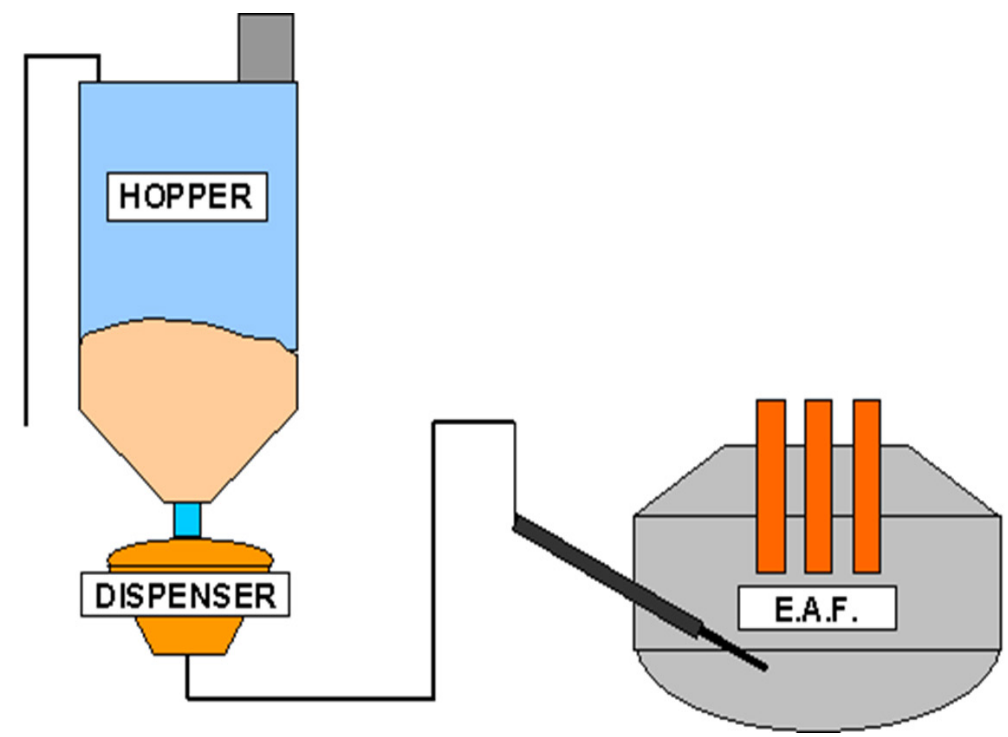

Figure 10. LF slag re-injection in EAF 


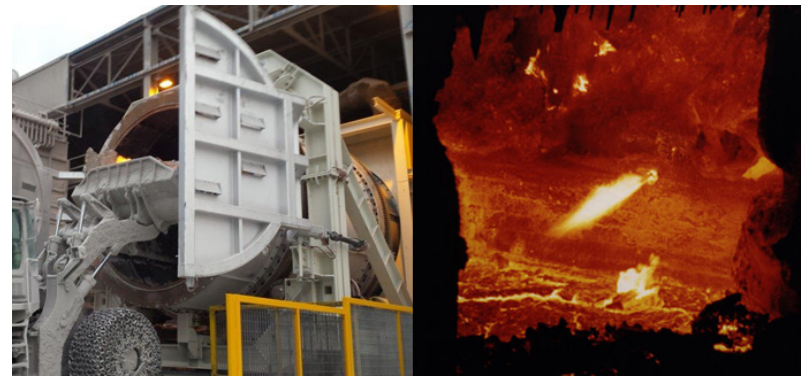

Figure 11. LF slag preparation plant and re-injection in EAF

The plant was built in 2001, since then it allows reuse of all LF slag and all refractories directly in the EAF. Last year LF slag preparation plant was upgraded with a patented rotating drum for cooling of LF slag; it is shown in Figure 11.

This process saves the equivalent of the lime content: about 30000 tpy. In this case, our EAF plant is the destination of the re-use process in a circular economy loop.

\subsection{Iron Scale}

It is known that metal iron is not stable: it combines with oxygen of air to return to the form of oxide. All surfaces of steel products are covered with a layer of oxide that is more consistent if formed at high temperatures. These oxides seemed particularly interesting materials, as they are iron very rich. In our case iron oxide is $>98 \%$ : no mineral is so rich! The job was to standardize the product to re-use it. We improved separation processes from cooling fluids. Now it is an interesting material with high iron content and new customers are interested in it: from chemical to cement industry or to steel production with blast furnace (BF). Also in this case about 30000 tpy are reused instead of wasting it.

\subsection{Scrap}

EAF was developed and is increasing its shear in steel production worldwide due to scrap availability and reuse. Also in Ferriere Nord case, scrap is our main input material. In this case we are downstream in the process, we are the customers and scrap dealers are producers. Scrap quality connected to analysis, to tramp elements, to oxidation and finally to inert or non-ferrous materials content is the main issue in our process. A loop of circular economy related to scrap is already active, but some new aspects need to be highlighted: usually surface covering or protection of steel and, at end of life, its presence on scrap is considered as a negative aspect in relation to EAF process. Particularly Zinc content can be regarded as a negative factor in evaluation of steel scrap value. This is due to Zinc evaporation in EAF process followed by re-oxidation in dust collecting plant. High contents of zinc determine, if not properly managed, difficulties in environmental and economical performances of EAF. Another way to face the problem is illustrated in Figure 12 where a possible problem is seen as an opportunity. EAF is used to recover iron and this originates the loop already known but EAF can be considered as a mean to separate and collect Zinc for reuse. A new loop is activated with Zinc. In Figure 12 we describe this loop of Zinc with the processes that were tackled in Ferriere Nord experience, but other ways are already available or will be in the future. EAF evaporates zinc as metal from coated surfaces than it is re-oxidized. It follows a pyrometallurgical process as Indutec ${ }^{\circledR}$ which concentrates and starts purification before an electrowinning process where metallic zinc is prepared just ready to be reused in protection of steel.

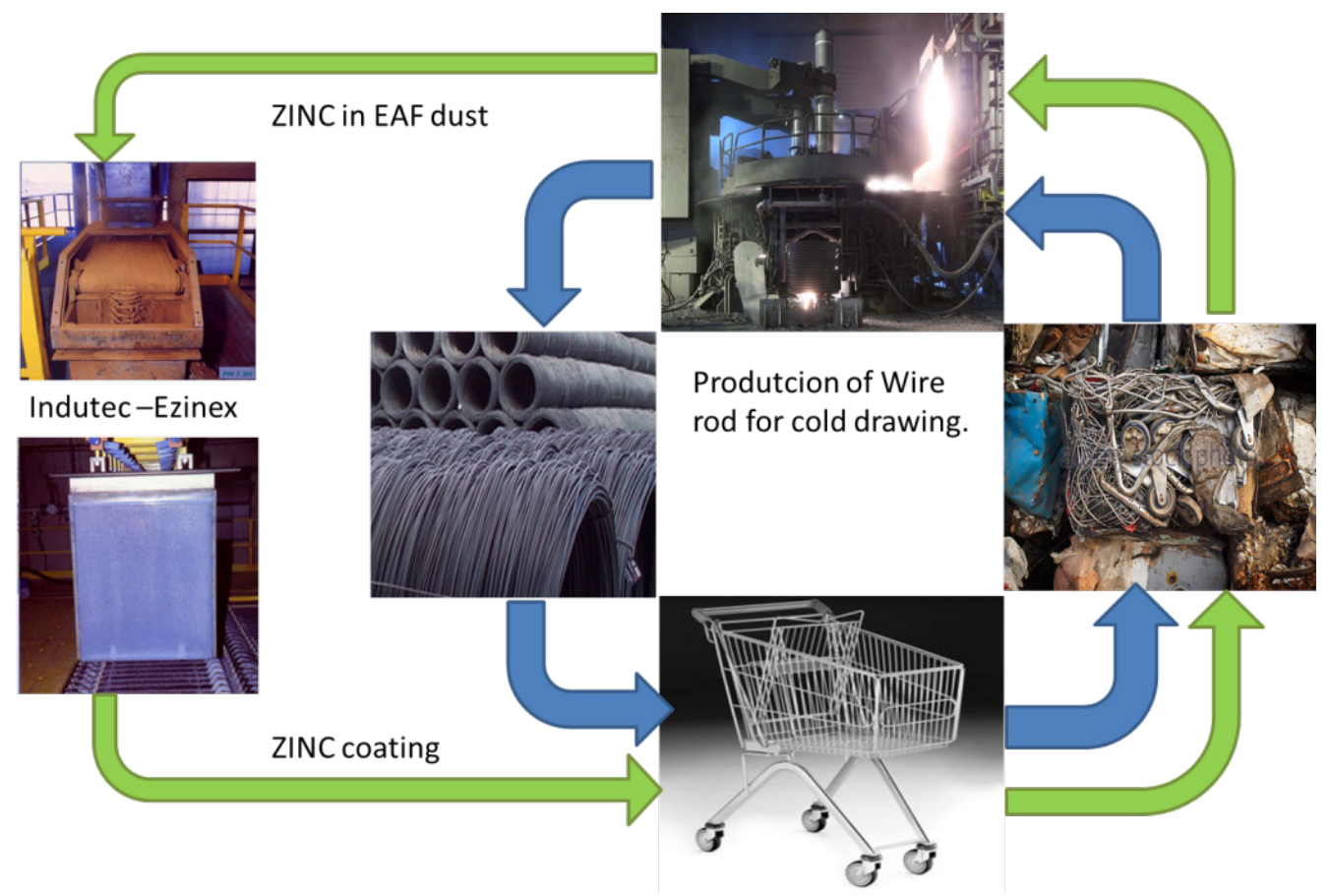

Figure 12. Iron and Zinc loops of circular economy. 


\subsection{Results}

All above reported is a regular practice in Ferriere Nord. The following table 5 summarizes materials quantities handled by Ferriere Nord in Osoppo Plant with a logic of circular economy since Zero Waste project and equivalent materials saved. These results are an important factor of competitiveness from an economical point of view, moreover they are important as our company is perceived for its environmental behavior: saving of energy, of resources, of $\mathrm{CO}_{2}$ emissions enhances our sustainability. [1]

Table 5. Quantities of natural material substituted and potential at European level

\begin{tabular}{|c|c|c|c|}
\hline Materials & $\begin{array}{c}\text { Ferriere } \\
\text { Nord }\end{array}$ & $\begin{array}{c}\text { Ferriere Nord } \\
1998-2016\end{array}$ & $\begin{array}{c}\text { Natural material } \\
\text { substituted }\end{array}$ \\
\hline Ktpy & Kt & Iron ore \\
\hline EAF slag & 200 & 3500 & Basalt, porphyry \\
\hline $\begin{array}{c}\text { LF slag and } \\
\text { refractories }\end{array}$ & 30 & 460 & Lime \\
\hline EAF dust & 25 & 380 & Zinc ore \\
\hline Iron scale & 30 & 450 & Iron ore \\
\hline
\end{tabular}

\subsection{Future Developments in Circular Economy}

An overview of the new situation after zero waste experience is reported in figure 13. In the center Ferriere Nord process receives steel scrap from end of life steel products and transforms it in new steel goods that join steel produced starting from iron ore with Blast Furnace, BOF route (left side of the figure). Ferriere Nord main secondary materials are transformed in new products and re-circulated in other processes: EAF slag in concrete asphalt plants, EAF dust in zinc production, iron scale in iron production, LF slag in the same EAF as substitute of lime.

The net result of this new configuration of processes allows saving of natural materials, iron ore, limestone, zinc ore, basalt stones. Moreover for each natural resource saved also the relative energy and $\mathrm{CO} 2$ saving is an important result as consequence of no mining, in case of iron or zinc ore, basalts, limestone, no primary transformation, no transport or limited transport if new products are delivered on local market like in the case of slags and iron scale.

At European level all these materials and their reuse are now considered in Best Available Technologies [8]. The situation is nowadays changed respect to 1998 when Zero Waste project started, but still not all residues are reused in Europe and in Italy: most of LF slag is landfilled, 30\% of EAF slag is landfilled, while EAF dust and iron scale are mostly reused. Circular Economy can be extended further at European or Italian level looking at processes with the method described at beginning of this paper to find the right way for the specific plant.

The experience gained with Zero Waste project is not considered to be closed and circular economy can be extended to other aspects. Energy is the second important item in the economy of steel production in EAF. Energy is used mainly to melt scrap and to reheat steel to shape it in rolling process. After process energy contained in steel is wasted. Temperatures in EAF and in rolling process are very high: $1600^{\circ}$ and $1100^{\circ} \mathrm{C}$ respectively, so an enormous quantity of energy is available and can be recovered instead of wasting it. A particular aspect to consider is that most of this energy is now wasted heating up fluids like water and air. A great effort will be devoted to imagine ways to recover and to use most of it. Also in this aspect circular economy can help to find ways to get rid of the problem involving our process directly or neighborhood industrial district or villages.

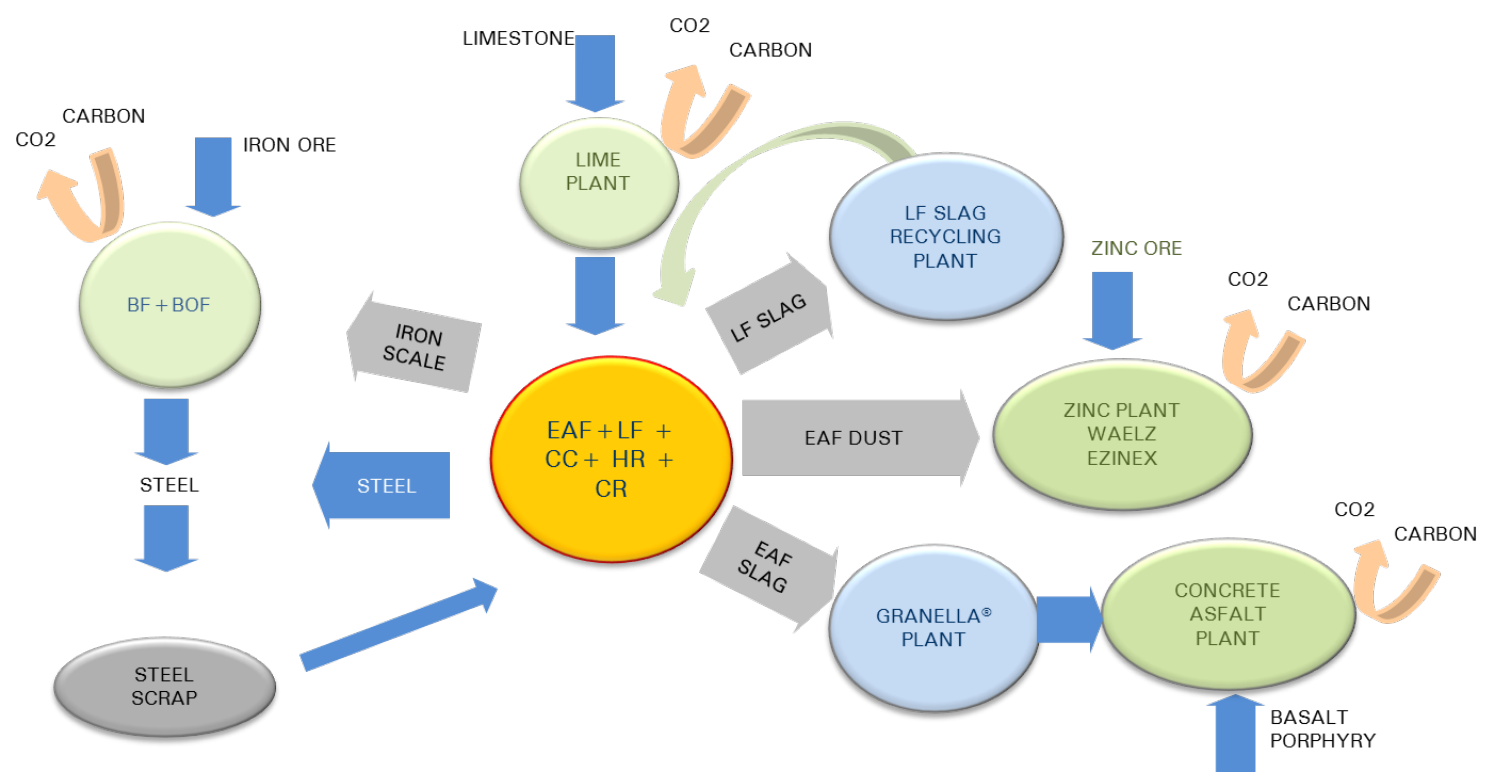

Figure 13. Ferriere Nord Process in a logic of circular economy after Zero Waste project 
Another material to be tackled is water. In EAF and rolling process water is mainly used as a media to cool down plants or steel. Recycling of water is the first issue so the first client is process itself. But also in this case circular economy can help to find smart solutions also for the remaining part. Finally we are looking to the other input materials involved as minor quantities in the process: carbon bearing materials as substitutes of fossil carbons or fuels [9], calcium bearing materials as slag integrators. Many opportunities are growing as circular economy is spreading: in this case it is necessary a careful selection based on analysis, compatibility to EAF process, economy of the global process.

\section{Conclusions}

If we have a look to Ferriere Nord case, after twenty years "Zero Waste" project, we can see that many loops of circular economy have been closed dealing with materials that in a logic of linear economy should be disposed: scrap, EAF slag, LF slag, spent refractories, EAF dust, iron scale. Many other companies have been involved in a logic of industrial symbiosis to deal with these materials to prepare, transform or finally use them: scrap dealers, lime and zinc producers, aggregates and asphalt producers, highway companies. Finally reuse of these materials allows saving of equivalent quantities of natural resources: iron ore, basalt, porphyry, limestone, zinc and lead minerals. Moreover saving these natural resources allows a reduction of energy consumption and consequently $\mathrm{CO}_{2}$ emissions.

Looking back to our experience, many years ago, we started to study and transform the main wastes into products, and at beginning, the driving force was high costs and difficulties to dispose wastes. During years we observed a growing tightness of environmental rules and a growing awareness in all stakeholders of our activity about environmental issues. After this experience we learned how to make sustainable our business. Meaning that all environmental, economic and social aspects must find an answer in the solution proposed to the problem.

\section{REFERENCES}

[1] L. Bianco, S. Porisiensi "From Linear to Circular Economy in Ferriere Nord: ladle Slag and Biomass case studies" -La metallurgia italiana" n. $10-2016$.

[2] L. Bianco "Zero waste esperienza di Un'acciaieria elettrica" Enco Journal n $38-392007$

[3] S. Porisiensi, M Maschietto, P Grandesso "Scorie di acciaieria: un nuovo aggregato ad elevate caratteristiche per conglomerati bituminosi speciali", www.buildup.it (tecnologie stradali) 2005

[4] Del Fabbro M., Stefanutti M., Ceschia C., "Impiego di derivati delle scorie di forno ad arco elettrico come materiale eco-compatibile nella sovrastruttura stradale", www.buildup.it (tecnologie stradali) 2005

[5] Ezinex and Indutec processes: www.engitec.com

[6] L. Bianco, C. Ceschia, S. Porisiensi "Integrated processing of steelworks EAF wastes" ECSC N7215-AA/403 - EU Publications 2000

[7] S. Porisiensi- "Recycling of ladle slag and spent refractories by injection into an EAF" - Iron \& Steel Technology June 2004

[8] BREF, Iron and Steel production, 2012 pag 419-479: http: //eippcb.jrc.ec.europa.eu/reference/BREF/IS_Adopte d_03_2012.pdf

[9] L. Bianco et al. - Sustainable Electric Arc Furnace steel Production GREENEAF.-BHM, 158.Jg..((2013), Heft 1/ Springer-Verlag Wien 